\title{
Gene therapy for alpha 1-antitrypsin deficiency with an oxidant-resistant human alpha 1-antitrypsin
}

\author{
Meredith L. Sosulski, Katie M. Stiles, Esther Z. Frenk, Fiona M. Hart, Yuki Matsumura, \\ Bishnu P. De, Stephen M. Kaminsky, and Ronald G. Crystal
}

Department of Genetic Medicine, Weill Cornell Medical College, New York, New York, USA.

\begin{abstract}
Alpha 1-antitrypsin (AAT) deficiency, a hereditary disorder characterized by low serum levels of functional AAT, is associated with early development of panacinar emphysema. AAT inhibits serine proteases, including neutrophil elastase, protecting the lung from proteolytic destruction. Cigarette smoke, pollution, and inflammatory cell-mediated oxidation of methionine (M) 351 and 358 inactivates AAT, limiting lung protection. In vitro studies using amino acid substitutions demonstrated that replacing M351 with valine (V) and M358 with leucine (L) on a normal M1 alanine (A) 213 background provided maximum antiprotease protection despite oxidant stress. We hypothesized that a onetime administration of a serotype 8 adeno-associated virus (AAV8) gene transfer vector coding for the oxidation-resistant variant AAT (A213/V351/L358; 8/AVL) would maintain antiprotease activity under oxidant stress compared with normal AAT (A213/M351/M358; 8/AMM). 8/AVL was administered via intravenous (IV) and intrapleural (IPL) routes to C57BL/6 mice. High, dose-dependent AAT levels were found in the serum and lung epithelial lining fluid (ELF) of mice administered 8/AVL or 8/AMM by IV or IPL. 8/AVL serum and ELF retained serine protease-inhibitory activity despite oxidant stress while 8/AMM function was abolished. 8/AVL represents a second-generation gene therapy for AAT deficiency providing effective antiprotease protection even with oxidant stress.
\end{abstract}

Authorship note: MLS and KMS contributed equally to this work.

Conflict of interest: RGC has equity in LEXEO, SMK is a consultant to LEXEO, and MLS, KMS, BPD, SMK, and RGC are participants in a patent disclosure (US20200102575A1) regarding oxidant-resistant gene therapy for alpha 1-antitrypsin deficiency.

Submitted: December 27, 2019

Accepted: July 1, 2020

Published: August 6, 2020

Reference information: JCI Insight 2020;5(15):e135951.

https://doi.org/10.1172/jci. insight.135951.

\section{Introduction}

Alpha 1-antitrypsin (AAT) deficiency is a common autosomal recessive disorder affecting $1 / 2000$ to 1/5000 individuals, about 90,000 people in the United States (1-5). The primary manifestation of AAT deficiency is early-onset panacinar emphysema. The disease, which is accelerated by smoking, presents at ages 35 to 40 in smokers compared with ages 55 to 60 in nonsmokers $(1,3,6-8)$. AAT is a serine protease inhibitor that functions to inhibit neutrophil elastase (NE) as well as other neutrophil-released serine proteases, including proteinase $3, \alpha$-defensins, and cathepsin $\mathrm{G}(1,2,6,9-13)$. AAT is produced predominantly in the liver and diffuses across the lung from the circulation $(1,2,4,6,9,14-16)$. In the lung, AAT is also produced locally by monocytes, macrophages, alveolar epithelial type 2 cells, and bronchial epithelial cells (17-19). However, hepatocytes produce the vast majority of functional AAT as AAT-deficient patients who receive liver transplants convert to the donor AAT phenotype (20-22). Low serum levels of AAT, and thus in the alveolar structures and alveolar epithelial lining fluid (ELF), are associated with an imbalance between AAT and neutrophil-released proteases, leading to the slow destruction of the lung parenchyma $(1,2,4,6,9,14,16,23)$

AAT deficiency is caused by mutation in the SERPINA1 gene, a member of the serpin family of antiproteases $(3,5,24,25)$. The normal $\mathrm{M}$ alleles are present in more than $98 \%$ of the population $(3,5)$ Although there are more than 120 known alleles of AAT, individuals homozygous for the Z allele (E342K) account for more than $95 \%$ of clinically recognized cases of AAT deficiency $(2,4,6,23,26-28)$. The Z allele causes the AAT protein to polymerize in hepatocytes, limiting secretion into the circulation, resulting in plasma levels $10 \%$ to $15 \%$ of the levels of normal $\mathrm{M}$ homozygotes $(4,5,7,29-31)$.

AAT binds serine proteases through its active site centered at methionine (M) 351 and 358 (M358, M351) through an irreversible interaction that inactivates both the protease and AAT $(32,33)$. These M residues in AAT are inactivated by exogenous oxidants, including cigarette smoke and air pollutants and endogenous oxidants 
from activated inflammatory cells $(34,35)$. Under oxidizing conditions, the M351 and M358 in the active site are oxidized to methionine sulfoxide, significantly reducing the ability of AAT to function (36-42). AAT in lung ELF of smokers has markedly reduced ability to inhibit NE compared with nonsmokers $(34,43,44)$; this sensitivity of AAT to oxidants is the reason behind the early occurrence of emphysema in smokers with AAT deficiency $(44,45)$.

The current therapy for AAT deficiency is augmentation with weekly infusions of purified AAT from pooled human plasma $(9,46-48)$. The infusion of AAT protein normalizes AAT levels in the serum and corrects the deficiency of levels in lung ELF, protecting the alveoli from proteolytic destruction $(9,46,47)$. While AAT augmentation therapy is safe and reduces the rate of lung destruction in AAT-deficient individuals (49-52), protein augmentation therapy requires a treatment regimen of weekly parenteral infusions and has the theoretical risks associated with human plasma-derived products, such as allergic reactions and viral contamination $(48,53,54)$.

Gene therapy is a strategy to circumvent both the requirement of weekly administration of the AAT protein and the sensitivity of AAT to oxidants. First-generation gene therapy strategies for the treatment of AAT by our group and others have used the coding sequence from the normal M1 allele, which is an effective inhibitor of serine proteases but has M351 and M358 residues that are vulnerable to oxidation (55-73). Our lab and others have demonstrated that changing either the active site M351 or M358 to valine (V) or leucine (L) can prevent oxidation while maintaining serine protease-inhibitory capacity (40, 74-81). Based on these studies, we hypothesized that a second-generation adeno-associated virus serotype 8 (AAV8) gene transfer vector coding for an oxidant-resistant AAT would maintain function even under oxidizing conditions. The data demonstrate that in vivo gene therapy with AAT with modified M351 to V and M358 to L (AAT-AVL) results in persistent expression of AAT at high levels in serum and lung ELF in mice. The vector-produced AAT-AVL retains function in the presence of excess oxidants and represents a second-generation strategy to treat AAT deficiency.

\section{Results}

Optimization of an oxidant-resistant AAT gene. Individuals homozygous for the $\mathrm{Z}$ allele account for more than $95 \%$ of clinically recognized cases of AAT deficiency $(1,4-6,23,27,28)$. Because the $Z$ allele is derived from the normal M1 alanine 213 (A213) allele (Figure 1A), we used the normal AAT M1(A213) coding sequence as the base of the transgene expression cassette, thus minimizing the theoretical possibility of immunity generated against the AAT transgene. Prior studies have shown that substitution of V or L for $\mathrm{M}$ at positions 351 or 358 in the AAT active site can prevent inactivation of AAT by oxidation (40, 74-78, 80-82) (Figure 1B). To determine the best combination of $\mathrm{V}$ and $\mathrm{L}$ substitutions for M351 and M358, all combinations of single and double substitutions were made by site-directed mutagenesis (Figure 1C). All AAT variants were produced in vitro and tested for their ability to inhibit NE and cathepsin G in the absence or presence of oxidants using NE and cathepsin G inhibition assays.

All AAT variants were able to inhibit NE under nonoxidizing conditions at levels similar to the WT (M351/M358) AAT (Figure 2A). However, in the presence of the oxidizer $N$-chlorosuccinimide (NCS), inhibitory activity of WT AAT was completely abolished (Figure 2B). Activity was also abolished for other AAT variants with M at position 358 (V351/M358, L351/M358). In contrast, variants with either V or L substituted in position 358 retained NE-inhibitory activity that was not significantly different from the inhibitory capacity in the absence of oxidant stress. Similar results were also found for NE inhibition in the presence of hydrogen peroxide $\left(\mathrm{H}_{2} \mathrm{O}_{2}\right.$; Figure $\left.2 \mathrm{C}\right)$. In the absence of oxidants, WT AAT inhibited approximately $40 \%$ of the cathepsin $\mathrm{G}$ activity (Figure $2 \mathrm{D}$ ). The variants with $\mathrm{V}$ at position 358 (M351/V358, V351/V358, L351/V358) were unable to inhibit cathepsin G while the variants with $\mathrm{M}$ or $\mathrm{L}$ at position 358 retained this ability. In the presence of NCS, the ability of WT AAT to inhibit cathepsin G was eliminated (Figure 2E). Interestingly, only 3 variants, M351/L358, V351/L358, and L351/L358, inhibited cathepsin G in the presence of NCS. The same 3 variants were also able to inhibit cathepsin $\mathrm{G}$ with $\mathrm{H}_{2} \mathrm{O}_{2}$ (Figure $2 \mathrm{~F}$ ).

The 3 AAT variants (M351/L358 [8/AML], V351/L358 [8/AVL], and L351/L358 [8/ALL]) that retained NE- and cathepsin G-inhibitory capacity in the presence of NCS and $\mathrm{H}_{2} \mathrm{O}_{2}$ were packaged into AAV8 capsids for testing in mice in vivo (Supplemental Figure 1; supplemental material available online with this article; https://doi.org/10.1172/jci.insight.135951DS1). C57BL/6 mice ( $n=5$ males/group) were administered $10^{11}$ genome copies (gc) intravenously (IV), and serum was collected after 4 weeks to 
A

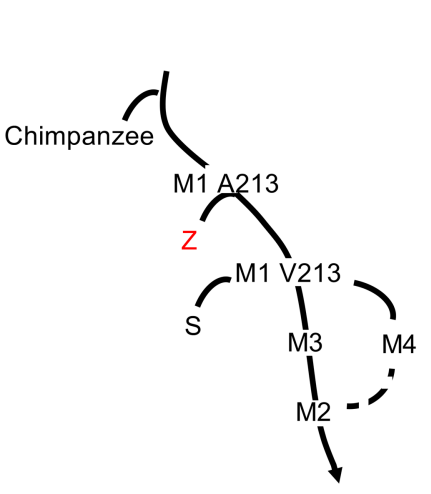

B

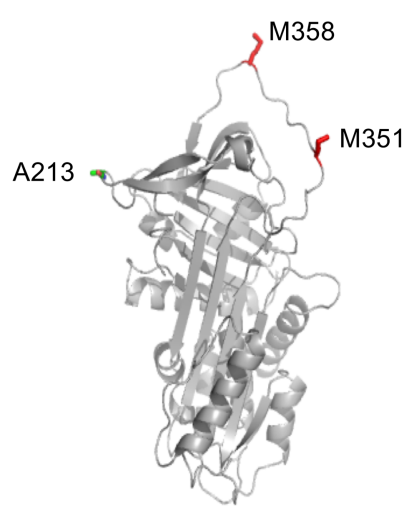

C

\begin{tabular}{cc}
\multicolumn{2}{c}{ Residue } \\
\hline 351 & 358 \\
\hline M & M \\
M & V \\
M & L \\
V & M \\
L & M \\
V & V \\
V & L \\
L & V \\
L & L
\end{tabular}

Figure 1. Design of a second-generation gene therapy for AAT deficiency. (A) Phylogenetic tree of AAT evolution (101, 102). $M 1(A 213), M 1(V 213), M 2, M 3$, and $M 4$ are all normal variants. The common $Z$ variant is derived from $M 1(A 213)$. The less common $S$ deficiency allele is derived from M1(V213). Since more than $95 \%$ of all AAT-deficient individuals are $Z Z$ homozygotes, the M1(A213) normal variant was used as the base for the second-generation AAT gene therapy constructs to minimize immune responses to the therapy. (B) Three-dimensional schematic of human AAT with the A213 normal variant and active site methionine residues (M351, M358) indicated (red). (C) AAT variants tested.

assess NE- and cathepsin G-inhibitory capacity in the presence of the NCS oxidant. AAT from 8/AMM (A213/M351/M358) could inhibit only 12\% of NE activity under oxidizing conditions. In contrast, AAT from 8/AML, 8/AVL, and 8/ALL retained significantly higher NE-inhibitory capacity in the presence of NCS compared with WT 8/AMM (Figure 3A). Cathepsin G-inhibitory activity of WT AAT from 8/AMM was abolished with NCS. In contrast, AAT from 8/AML, 8/AVL, and 8/ALL were all significantly better at inhibiting cathepsin $\mathrm{G}$ under oxidizing conditions than 8/AMM (Figure 3B). Overall, the $8 / \mathrm{AVL}$ construct performed the best of the 3 variants and was chosen for further studies.

Binding association rates to NE of AAT-AMM and AAT-AVL. AAT irreversibly binds and inhibits NE (32, 35). Surface plasmon resonance was used to calculate the association rate constant $\left(K_{a}\right)$ for the interaction between in vitro-produced AAT-AMM or AAT-AVL and NE under normal and oxidizing conditions. Under normal conditions, both AAT-AMM and AAT-AVL bound rapidly to NE with $K_{a}$ of $3.45 \times 10^{4} \pm$ $4.15 \times 10^{3} \mathrm{M}^{-1} \mathrm{~s}^{-1}$ for AAT-AMM and $1.60 \times 10^{4} \pm 5.65 \times 10^{3} \mathrm{M}^{-1} \mathrm{~s}^{-1}$ for AAT-AVL (Figure 4, A and B; and Table 1). These association rates are comparable to AAT from normal human serum $\left(K_{a}=2.84 \times 10^{4} \pm\right.$ $2.17 \times 10^{3} \mathrm{M}^{-1} \mathrm{~s}^{-1}$, normal serum vs. AAT-AMM, $P>0.7$; normal serum vs. AAT-AVL, $\left.P>0.2\right)$. Strikingly, in the presence of NCS, AAT-AMM showed little binding to NE, while AAT-AVL bound to NE similarly to normal conditions ( $K_{a}=1.59 \times 10^{4} \pm 5.78 \times 10^{3} \mathrm{M}^{-1} \mathrm{~s}^{-1}$; Figure $4, \mathrm{C}$ and D; and Table 1 ). AAT-AMM NE-inhibitory capacity was abolished under oxidizing conditions because there was no binding to NE, while AAT-AVL NE-binding and -inhibitory capacity was retained.

Evaluation of a second-generation oxidant-resistant AAT gene therapy in vivo. Because of the superior ability of AAT-AVL to inhibit NE and cathepsin G under oxidizing conditions, we hypothesized that a onetime IV administration of 8/AVL would provide high levels of AAT in the serum and lung ELF that could effectively inhibit NE under oxidizing conditions. Based on prior studies demonstrating that intrapleural (IPL) administration yielded higher lung ELF levels (55), IPL administration was compared with IV administration. To evaluate this hypothesis, we administered $4 \times 10^{10}, 10^{11}$, or $4 \times 10^{11} \mathrm{gc}$ of $8 / \mathrm{AVL}$ oxidation-resistant variant via IV and IPL routes to male and female 6 - to 8 -week-old C57BL/6 mice ( $n=5 /$ group). WT $8 /$ $\operatorname{AMM}\left(4 \times 10^{11} \mathrm{gc}\right)$ and $8 / \mathrm{Null}$ (no transgene; $4 \times 10^{11} \mathrm{gc}$ ) were used as controls. Vector DNA in the liver and serum and ELF human AAT levels and function were assessed at various time points. Vector DNA in the liver showed high, dose-dependent, sustained levels over 24 weeks for IV and IPL administration in male (Supplemental Figure 2, A and B) and female mice (Supplemental Figure 2, C and D). AAT levels in serum and ELF for both IV and IPL routes of administration showed dose-dependent increases (male: Supplemental Figure 3; female: Supplemental Figure 4). Quantification by ELISA demonstrated high levels of human AAT in serum from $8 / \mathrm{AVL}\left(4 \times 10^{11} \mathrm{gc}\right)$ that were comparable to those from 8/AMM through 24 weeks in male mice administered IV (Figure 5A; 24 weeks 8/AVL: $1826 \pm 201 \mu \mathrm{g} / \mathrm{mL} ; 8 / \mathrm{AMM}$ : $1117 \pm 323 \mu \mathrm{g} / \mathrm{mL}$ ) or IPL (Figure 5B; 24 weeks 8/AVL: $1785 \pm 455 \mu \mathrm{g} / \mathrm{mL}$; 8/AMM: $1557 \pm 389 \mu \mathrm{g} / \mathrm{mL}$ ). Similar results were 


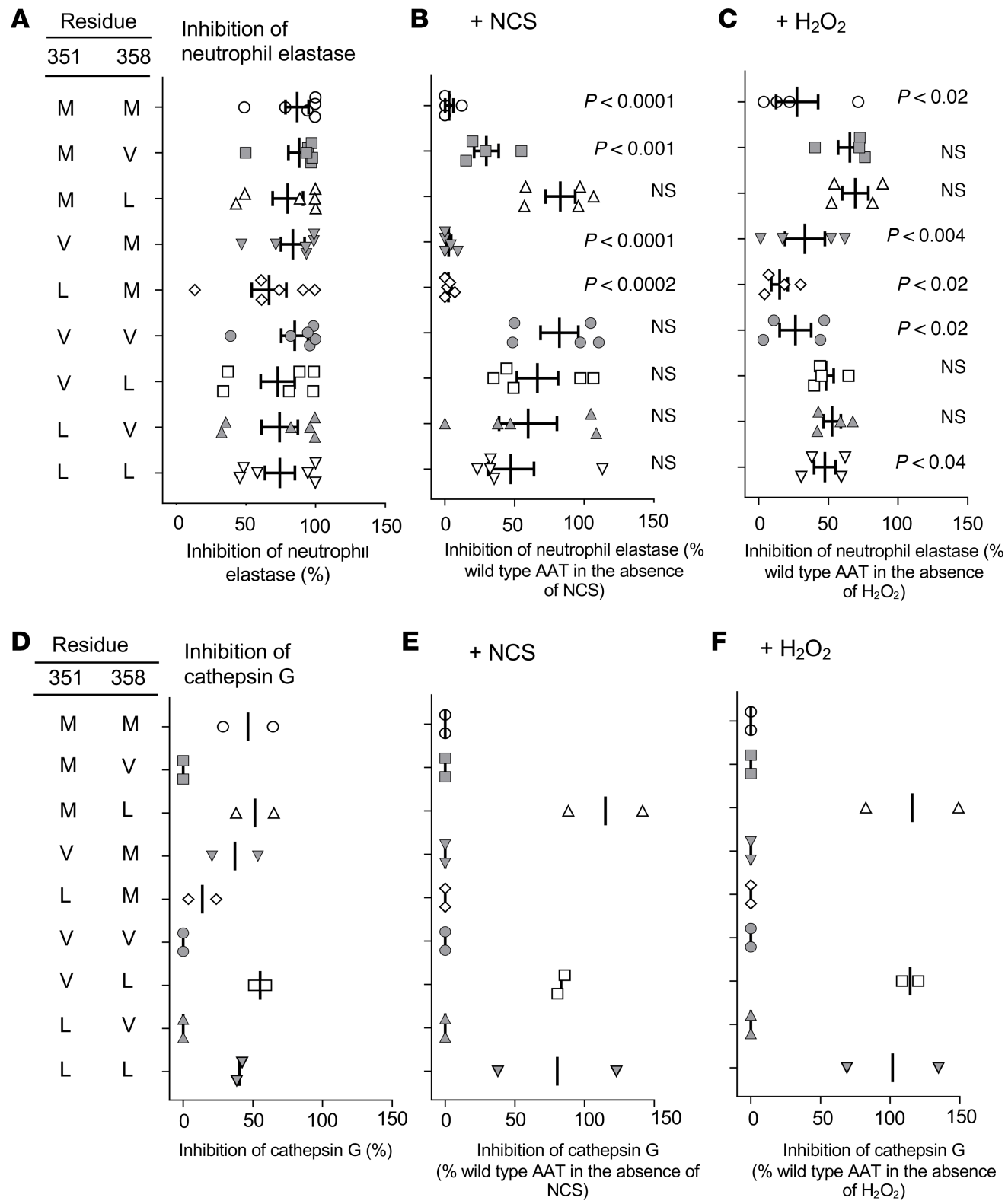

Figure 2. In vitro comparison of the ability of modified variants of human AAT to inhibit NE and cathepsin G under normal and oxidizing conditions. All data are presented as the percentage of WT inhibition in the absence of oxidizer. (A) NE inhibition by AAT variants under normal conditions $(n=6)$. (B) NE inhibition after exposure of AAT variants to $1 \mathrm{mM} \mathrm{NCS}$ for 20 minutes $(n=4)$. (C) NE inhibition after exposure of AAT variants to $250 \mathrm{mM} \mathrm{H}_{2} \mathrm{O}_{2}$ for 40 minutes $(n=4)$. (D) Cathepsin $G$ inhibition by AAT variants under normal conditions $(n=2)$. (E) Cathepsin $C$ inhibition after exposure of AAT variants to $1 \mathrm{mM} \mathrm{NCS}$ for 20 minutes $(n=2)$. (F) Cathepsin $\mathrm{G}$ inhibition after exposure of AAT variants to $250 \mathrm{mM} \mathrm{H}_{2} \mathrm{O}_{2}$ for 40 minutes $(n=2)$. Comparison for $P$ value is between inhibition under normal conditions and inhibition with either NCS or $\mathrm{H}_{2} \mathrm{O}_{2}$ for each AAT variant. Each assay was performed in triplicate and averaged for each independent experiment. Statistical analysis was performed by ANOVA.

found in female mice $\left(4 \times 10^{11} \mathrm{gc}\right)$, although the overall levels of AAT from both 8/AVL and 8/AMM were $1 \log$ lower (Figure 5, C and D). Sex differences in transgene levels have been described previously and are specific to mice $(61,83,84)$.

The function of AAT in serum from mice administered 8/AVL or 8/AMM $\left(4 \times 10^{11} \mathrm{gc}\right)$ was examined using the NE inhibition assay at several time points. Serum from 8/AVL- and 8/AMM-administered male mice showed similar levels of NE inhibition in the absence of oxidizers at 4,12 , and 24 weeks for both IV and IPL routes (Figure 6, A-F). In the presence of oxidants NCS or $\mathrm{H}_{2} \mathrm{O}_{2}$, NE inhibition by AAT from 8/AMM-administered mice was abolished. Importantly, AAT from serum of 8/AVL-administered mice 
A Anti-neutrophil elastase activity $+\mathrm{N}$ chlorosuccinimide

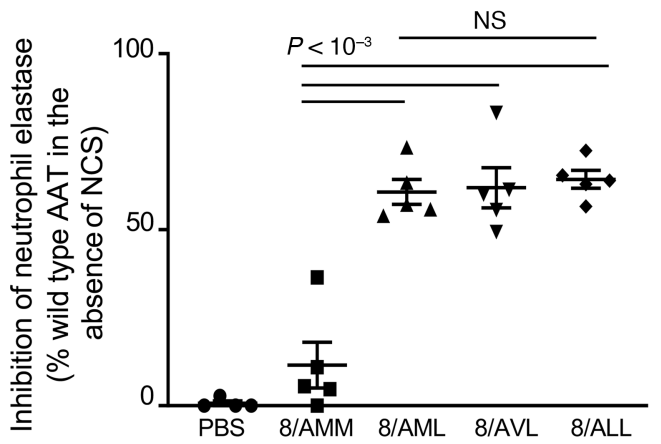

B Anti-cathepsin G activity $+\mathrm{N}$-chlorosuccinimide

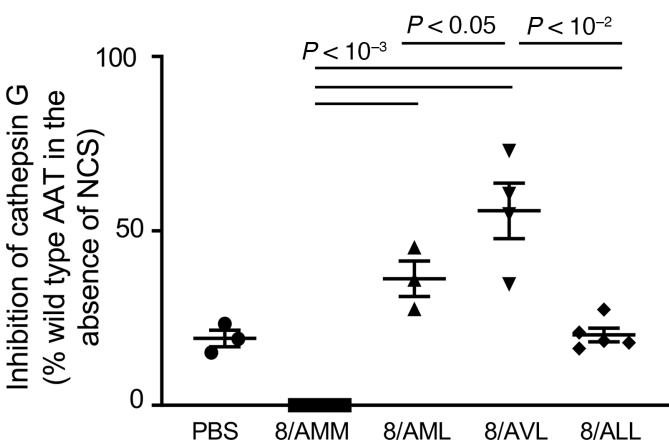

Figure 3. Comparison of in vivo-produced human AAT-modified variants' ability to inhibit NE and cathepsin G. AAV8 vectors expressing modified AAT variants were administered to $C 57 \mathrm{BL} / 6$ male mice (IV, $10^{11} \mathrm{gc}$ ), and serum was collected after 4 weeks. Human AAT levels were quantified by ELISA. An equal amount of each AAT variant was used in the protease inhibition assays. (A) Anti-NE activity. AAT variants were exposed to $1 \mathrm{mM}$ NCS for 20 minutes before addition of NE and substrate. NE inhibition is presented as the percentage of WT (8/AMM) inhibition in the absence of oxidizer. (B) Anticathepsin $\mathrm{G}$ activity. AAT variants were exposed to $1 \mathrm{mM} \mathrm{NCS}$ for 20 minutes before addition of cathepsin $\mathrm{G}$ and substrate. Cathepsin $\mathrm{C}$ inhibition is presented as the percentage of WT (8/AMM) inhibition in the absence of oxidizer. Experiments were performed in triplicate and averaged for $n=3-5$ mice per group, and statistical analysis was performed by ANOVA.

inhibited more than $50 \%$ of $\mathrm{NE}$ activity at all time points for both routes of administration, significantly higher than AAT from 8/AMM (all $P<0.03$ ). Similar results were found with AAT from serum of female mice administered 8/AVL by either the IV or IPL routes (Supplemental Figure 5, A-F). Additionally, AAT in serum from male mice administered 8/AVL IV or IPL at 24 weeks was able to inhibit NE in the presence of hypochlorous acid ( $\mathrm{HOCl})$, an oxidant produced by activated neutrophils (85), while activity of AAT from 8/AMM-administered mice was abolished (Supplemental Figure 6, A and B).

Human AAT levels in ELF of male mice after IV (Figure 7A) or IPL (Figure 7B) administration with $8 / \mathrm{AVL}\left(4 \times 10^{11} \mathrm{gc}\right)$ were $29.0 \pm 2.6 \mu \mathrm{g} / \mathrm{mg}$ and $30.2 \pm 4.7 \mu \mathrm{g} / \mathrm{mg}$, respectively, at 24 weeks. These levels were similar to those of the mice administered $4 \times 10^{11} \mathrm{gc} 8 / \mathrm{AMM}$ (IV: $25.0 \pm 7.2 \mu \mathrm{g} / \mathrm{mg}$; IPL: $31.7 \pm 6.3$ $\mu \mathrm{g} / \mathrm{mg}$ ). Female mice also showed consistent levels of human AAT in the ELF after IV (Figure 7C) and IPL (Figure 7D) administration out to 24 weeks $\left(4 \times 10^{11} \mathrm{gc}\right)$. When compared collectively across all doses and time points, the ratio of human AAT in the ELF/serum (per mg protein) after 8/AVL administration was significantly higher for the IPL administration compared with IV administration for both male and female mice (Figure 7, E and F). The ability of AAT in ELF to inhibit NE was assessed at 24 weeks. AAT from 8/AVL-administered mice retained significant inhibition of NE compared with AAT in ELF from 8/ AMM administered either IV or IPL (Figure 8, A and B). Similar results were found with AAT from ELF of female mice administered 8/AVL by either the IV or IPL routes (Supplemental Figure 5, G and H).

\section{Discussion}

AAT deficiency is a common hereditary disorder associated with early-onset emphysema and liver disease $(1-3,6-8)$. AAT, a serine protease inhibitor, functions to protect the lung from destruction by neutrophil-released proteases, such as NE $(1,2,4,6,9,10,13)$. Greater than $95 \%$ of clinical cases of AAT deficiency result from low levels of AAT from the $\mathrm{Z}$ allele of the SERPINA1 gene $(1,2,4-6,23,26-28)$. The approved therapy for AAT deficiency is weekly infusions of purified AAT from pooled human plasma $(9,46-48)$. While this treatment is safe and effective, there is a high burden of cost as well as the requirement for repeated treatments for a lifetime. Further, AAT is susceptible to oxidant-mediated inactivation by both endogenous (inflammatory cells) and exogenous (cigarette smoke, pollution) oxidants, leaving it incapable of functioning as an antiprotease.

To overcome the shortcomings of the current treatments for AAT deficiency, we have developed an AAV-mediated gene therapy strategy using an AAV8 gene transfer vector coding for an oxidant-resistant AAT (8/AVL). The data demonstrate that administration of 8/AVL by either the IV or IPL route mediates high, persistent levels of AAT in the serum and ELF comparable to WT 8/AMM for at least 6 months. 

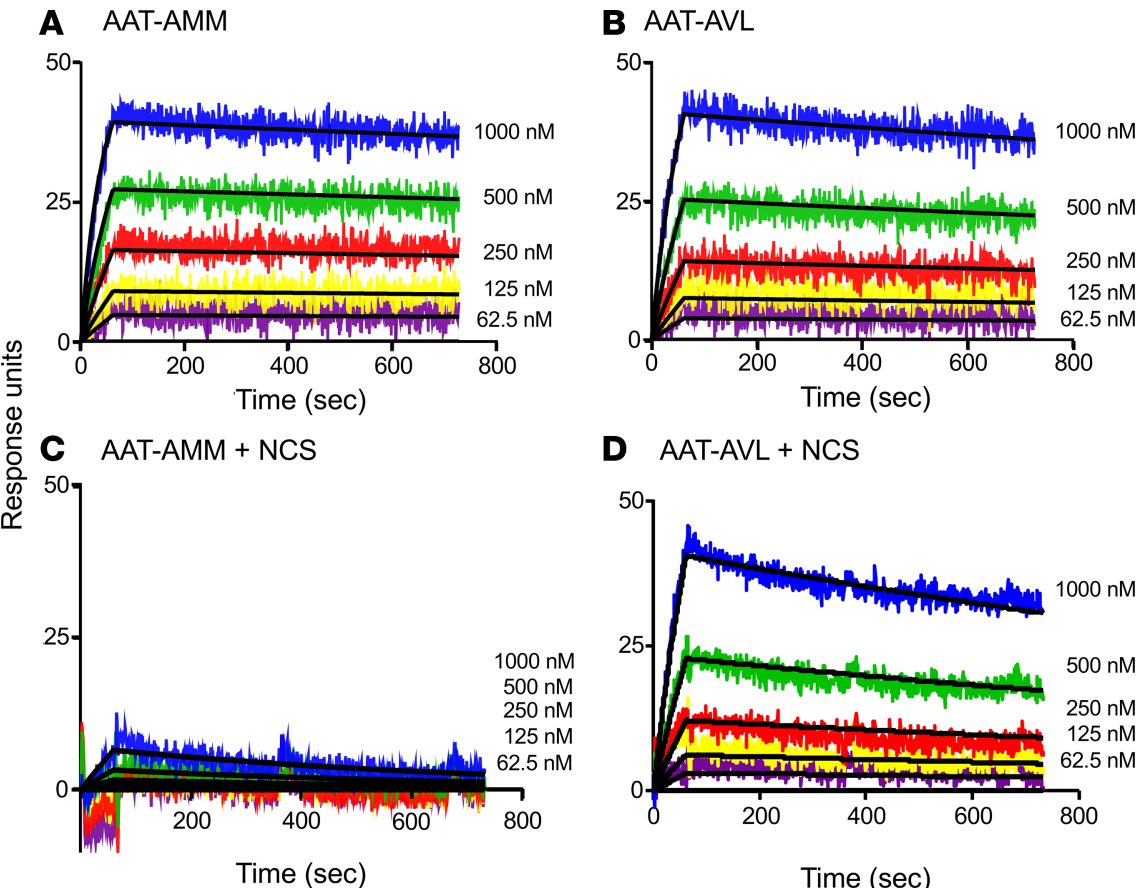

D $\quad$ AAT-AVL + NCS

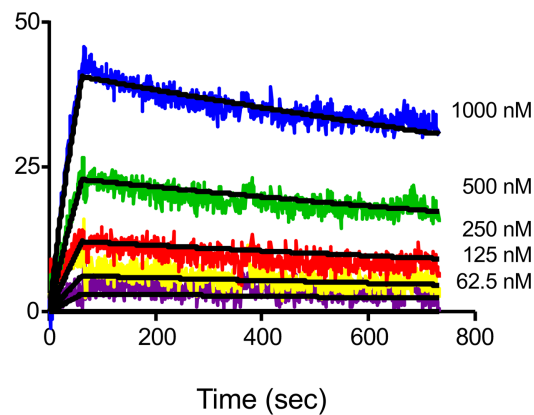

Figure 4. Association rates between human AAT and NE measured by surface plasmon resonance under normal and oxidizing conditions. NE was coupled to the sensor chip, and serial 2-fold dilutions of AAT were flowed across and allowed to bind (AAT: $1000 \mathrm{nM}$ shown in blue, $500 \mathrm{nM}$ shown in green, $250 \mathrm{nM}$ shown in red, $125 \mathrm{nM}$ shown in yellow, $62.5 \mathrm{nM}$ shown in purple). Curve fit to the Langmuir binding model (black line) (98). Binding curves are shown from 1 representative experiment of 3 independent experiments. (A) AAT-AMM binding to NE under normal conditions. (B) AAT-AVL binding to NE under normal conditions. (C) AAT-AMM binding to NE after exposure to 1 mM NCS for 20 minutes. (D) AAT-AVL binding to NE after exposure to $1 \mathrm{mM}$ NCS for 20 minutes. See Table 1 for association rates and statistical comparisons.

Importantly, AAT in serum or ELF from mice administered 8/AVL inhibited serine proteases even when exposed to an excess of oxidizing agents. 8/AVL gene therapy provides an AAT shield that will protect against serine proteases even in a lung environment persistently exposed to oxidants.

Oxidation of AAT in vivo. The lungs are constantly exposed to oxidizing agents both from endogenous sources, such as activated inflammatory cells, and exogenous sources, including air pollutants and cigarette smoke $(86,87)$. These oxidants inactivate AAT, making it incapable of inhibiting NE, cathepsin G, and other serine proteases that, if left unchecked, are destructive to the fragile alveolar structures. AAT recovered from the lungs of smokers has markedly lower functional activity than AAT

Table 1. Association rates of human AAT variants for neutrophil elastase assessed by surface plasmon resonance

\begin{tabular}{ccc}
\hline AAT variants $\mathbf{s}^{\mathrm{A}, \mathrm{B}}$ & Normal $\left(\mathbf{M}^{-1} \mathbf{s}^{-1}\right)$ & Oxidizing $\left(\mathbf{M}^{-1} \mathbf{s}^{-1}\right)^{\mathbf{c}}$ \\
\hline Normal human AAT & $2.84 \times 10^{4} \pm 2.17 \times 10^{3}$ & ND $^{D}$ \\
AAT-AMM & $3.45 \times 10^{4} \pm 4.15 \times 10^{3}$ & Under limit of detection \\
AAT-AVL & $1.60 \times 10^{4} \pm 5.65 \times 10^{3}$ & $1.59 \times 10^{4} \pm 5.78 \times 10^{3}$
\end{tabular}

NE elastase was coupled to the surface of the sensor chip, and serial 2-fold dilutions of AAT were flowed across to allow binding under normal and oxidizing conditions. Association rate constant $\left(K_{a}\right)$ was calculated using the Langmuir binding model. AATT-AMM and AAT-AVL were purified using an affinity column from culture media of 293T cells

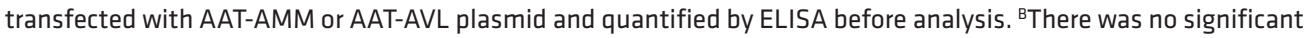
difference in the $K_{a}$ between normal human AAT, AAT-AMM, and AAT-AVL under normal conditions: normal vs. AATAMM, $P>0.7$; normal vs. AAT-AVL, $P>0.2$; AAT-AMM vs. AAT-AVL, $P>0.06$; statistical analysis was performed by ANOVA. ${ }^{\circ}$ One millimolar NCS for 20 minutes. ${ }^{\circ} \mathrm{ND}$, not done. 


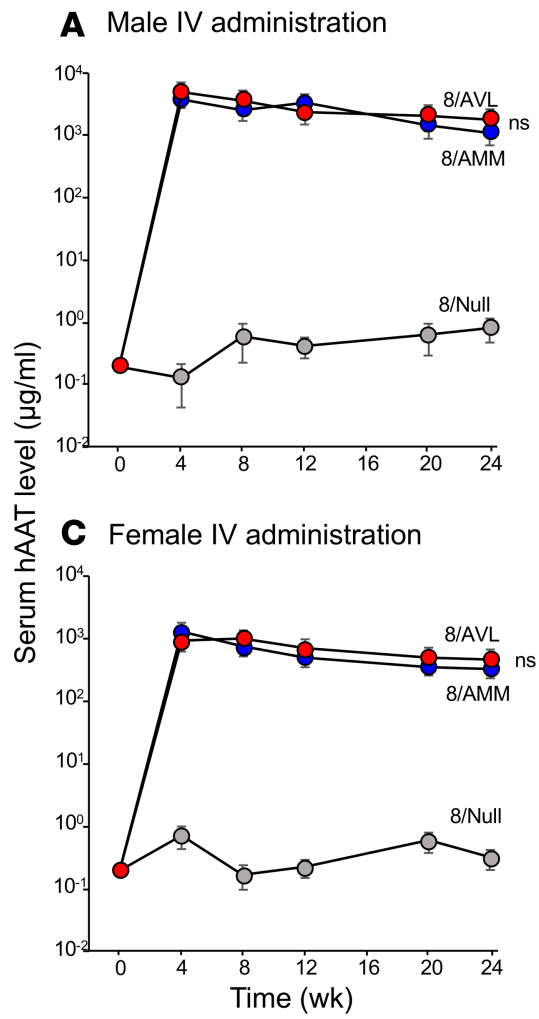

B Male IPL administration

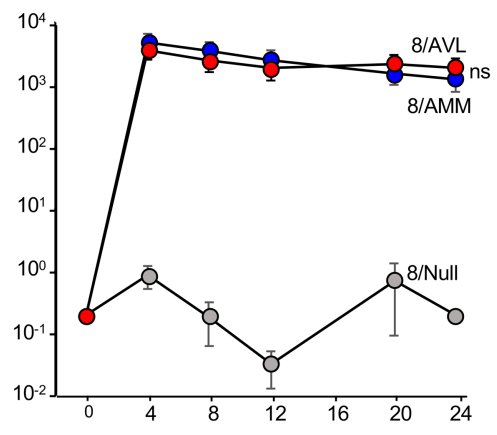

D Female IPL administration

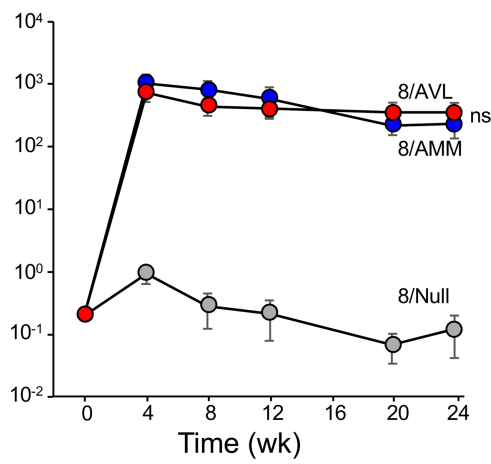

Figure 5. In vivo levels of human AAT variants in serum over time following IV or IPL administration in male and female mice ( $\boldsymbol{n}=\mathbf{4 - 5} /$ group). C57BL/6 mice were administered 8/AMM, 8/AVL, or 8/Null ( $4 \times 10^{11} \mathrm{gc}$ ) by IV and IPL routes. Serum was collected at 0, 4, 8, 12, 20, and 24 weeks, and human AAT was quantified by ELISA. (A) Male mice, IV. (B) Male mice, IPL. (C) Female mice, IV. (D) Female mice, IPL. At 24 weeks, there was no significant (ns) difference between 8/AMM and 8/AVL for either sex or administration route using Student's $t$ test.

recovered from nonsmokers (34). Further, alveolar macrophages recovered from the lungs of smokers spontaneously release greater superoxide and $\mathrm{H}_{2} \mathrm{O}_{2}$ than macrophages from nonsmokers, causing a $60 \%$ reduction in the ability of AAT to inhibit NE (88). Nonsmokers are still exposed to exogenous oxidants, such as pollutants, and thus there is likely a variable fraction of AAT in ELF that is actually active and able to inhibit proteases. Children with the ZZ genotype at high risk for developing lung disease show higher levels of oxidative stress markers in serum than children with the MM or MZ genotype (89). Thus, the susceptibility to oxidants likely contributes to the pathogenesis of emphysema in AAT-deficient individuals $(1-3,6-8)$.

Gene therapy for AAT deficiency. Gene therapy for AAT deficiency offers the potential for a onetime administration to provide therapeutic levels of AAT to protect the lung from destruction associated with the imbalance of proteases to antiproteases when AAT levels are low. Several strategies for gene therapy for AAT have been tested at the preclinical and clinical levels, but all have focused on delivering the normal human AAT M allele (55-73). The threshold level of AAT needed to be protective clinically is $11 \mu \mathrm{M}$ in serum and $1.2 \mu \mathrm{M}$ in $\operatorname{ELF}(2,25,47,54)$. While these levels have not been achieved in AAT gene therapy clinical trials to date $(59,60,63,68)$, these calculations are based on WT AAT, a portion of which may be inactivated by oxidation. Therapy with the oxidant-resistant 8/AVL may prove efficacious in alleviating disease at lower absolute levels of AAT protein because of the elevated percentage of antiprotease activity, and lower vector doses may be needed to achieve this protein level.

Protein therapy for AAT deficiency with oxidant-resistant AAT. Protein therapy studies support the proposed use of oxidant-resistant AAT as a therapy for AAT deficiency. Early studies showed that an active, nonglycosylated human AAT containing the M358V mutation produced in yeast was able to inhibit NE under a number of oxidizing conditions in vitro $(74,78,82)$. Similarly, recombinant human AAT with M358V, M358L, or M351V/M358V modifications produced in Escherichia coli showed oxidant resistance $(75,82,90)$. Human AAT M358V produced in the plant Nicotiana benthamiana maintained antiprotease 
A Male IV administration, serum 4 wk

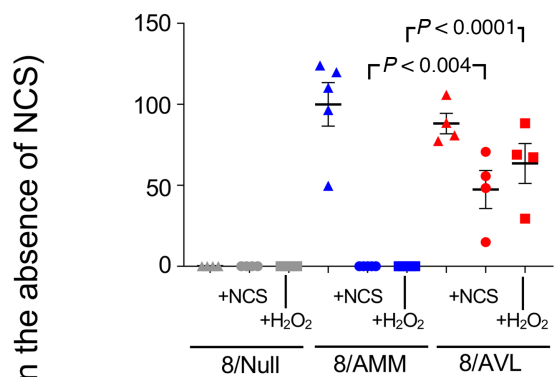

C Male IV administration, serum 12 wk

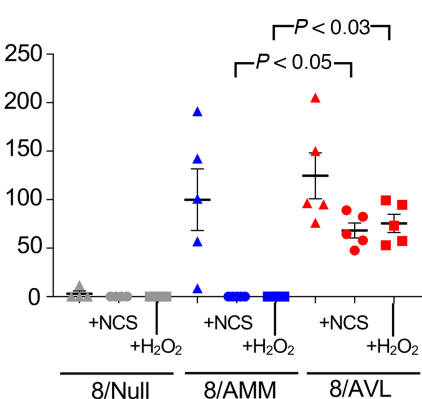

E Male IV administration, serum 24 wk

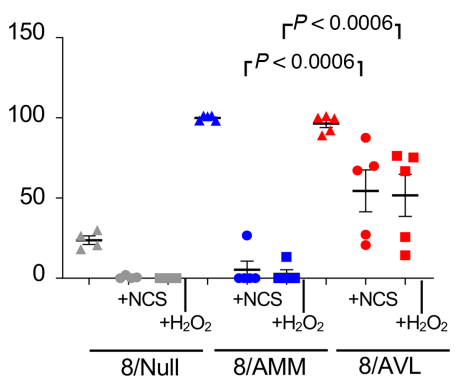

B Male IPL administration, serum $4 \mathrm{wk}$

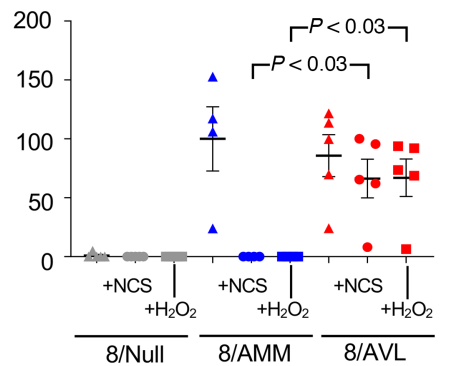

D Male IPL administration, serum $12 \mathrm{wk}$

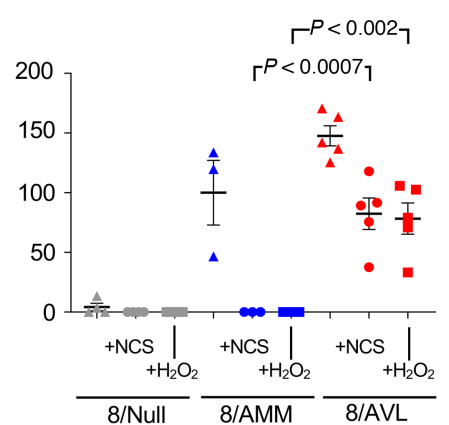

F Male IPL administration, serum 24 wk

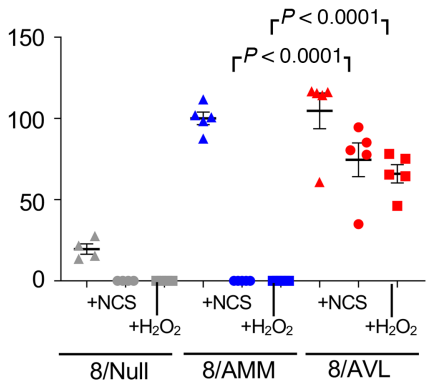

Figure 6. Anti-NE activity of human AAT in serum from male mice administered AAV8 vectors under normal and oxidizing conditions. C57BL/ 6 male mice were administered 8/AMM, 8/AVL, or 8/Null $\left(4 \times 10^{11} \mathrm{gc}\right)$ by IV and IPL routes. Serum was collected at 4, 12, and 24 weeks, and human AAT was quantified by ELISA. Equal amounts ( $50 \mathrm{nM})$ of AAT were used in the NE inhibition assay. Data are presented as the percentage of WT (8/AMM) NE inhibition in the absence of oxidizer. (A) IV, 4 weeks. (B) IPL, 4 weeks. (C) IV, 12 weeks. (D) IPL, 12 weeks. (E) IV, 24 weeks. (F) IPL, 24 weeks. Assays were run in triplicate and averaged for samples from $n=4-5$ mice/group, and statistical analysis was performed by ANOVA.

activity in the presence of oxidants compared with WT human AAT (80). Recombinant AAT fused to insulin-like growth factor produced in baculovirus with the M351 changed to glutamate (M351E) was a more potent inhibitor of NE than WT after incubation at room temperature for 24 hours (91). Recently, an oxidant-resistant recombinant human AAT-Fc fusion protein with M351E and M358L mutations (INBRX-101) was approved for testing in a phase I clinical study (81) (ClinicalTrials.gov NCT03815396). However, all of these oxidant-resistant AATs are recombinant proteins that would still need to be infused frequently, similar to the currently approved therapies $(9,46-48)$.

IV versus IPL routes of administration. Administration of $8 / \mathrm{AVL}$ by both the IV and IPL routes showed high levels of sustained AAT protein in the serum and ELF of both male and female mice. However, analyzing all doses and time points collectively, the ELF/serum ratio of AAT was significantly higher with the IPL administration route (Figure 7, E and F), suggesting that, for the same dose of the AAV vector, the IPL route may be more effective at defending the lung than IV administration. In addition to the mesothelial lining of the pleura as a site for gene expression directly in the lung, the parietal pleura has open stomata for lymphatics that allow for a slow release of the vector into the circulation, with consequent liver expression $(92,93)$. Thus, the IPL route provides for both local 


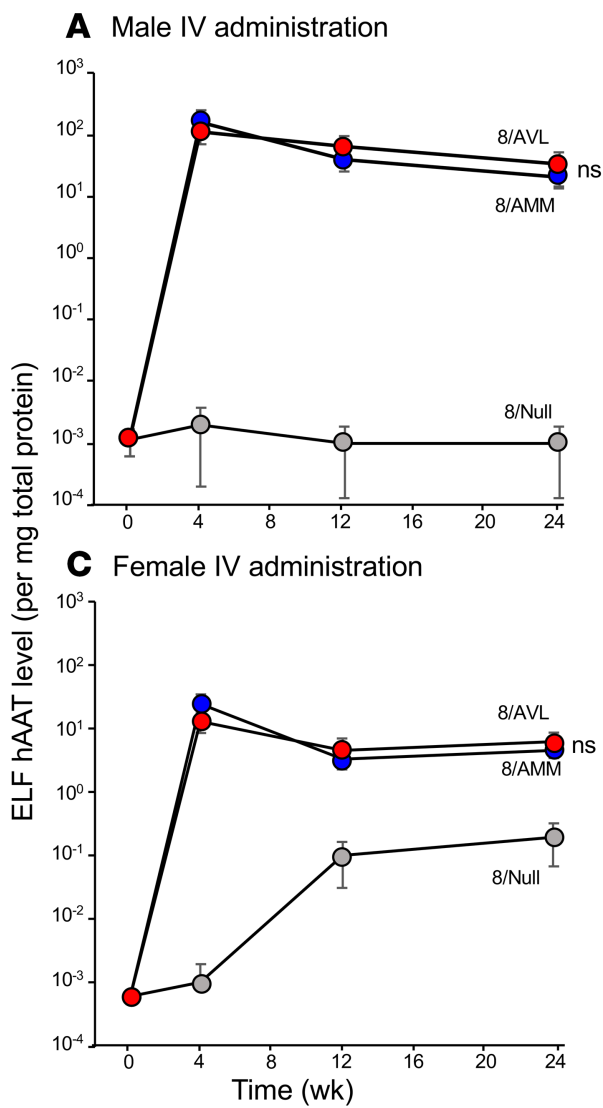

B Male IPL administration

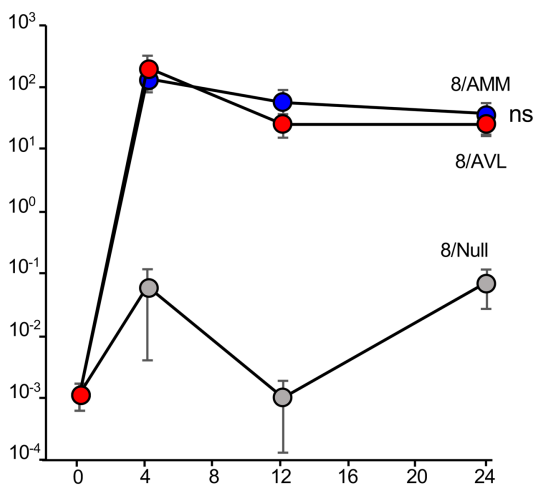

D Female IPL administration

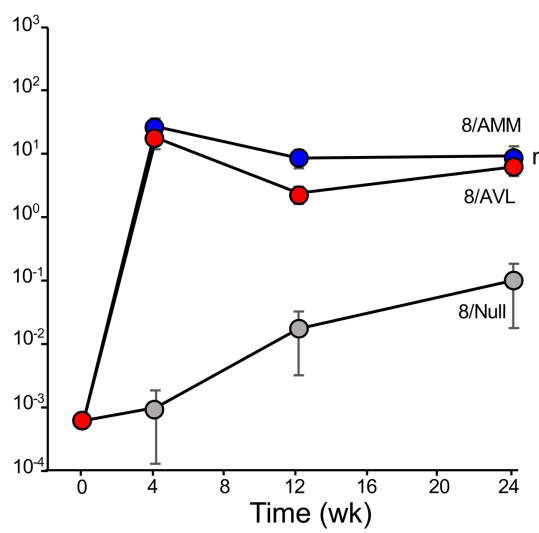

E Male

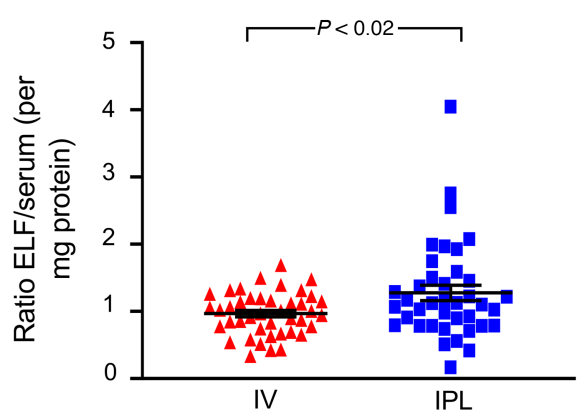

F Female

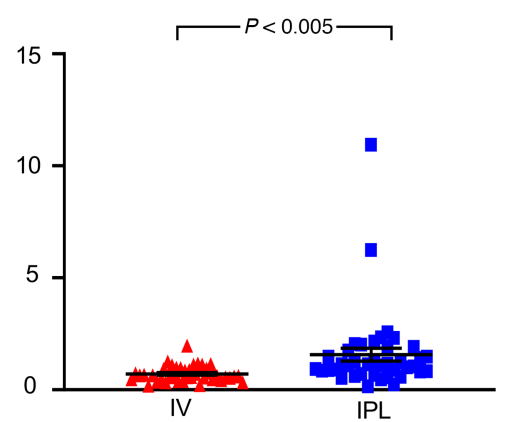

Figure 7. In vivo levels of human AAT in ELF over time following administration of the AAV8 vectors. C57BL/6 mice were administered $8 / \mathrm{AMM}, 8 / \mathrm{AVL}$, or $8 / \mathrm{Null}\left(4 \times 10^{11} \mathrm{gc}\right)$ by the IV and IPL routes $(n=4-5 /$ group $)$. Lung ELF was collected after sacrifice at $0,4,12$, or 24 weeks, and human AAT was quantified by ELISA. (A) Male mice, IV. (B) Male mice, IPL. (C) Female mice, IV. (D) Female mice, IPL. At 24 weeks, there was no significant (ns) difference between 8/AMM and 8/AVL for either sex or administration route using Student's $t$ test. (E and $\mathbf{F}$ ) Ratio of ELF to serum AAT. (E) Male mice. (F) Female mice. For $\mathbf{E}$ and $\mathbf{F}$, data from all doses and time points were combined, and AAT levels (per mg protein) were collectively compared in ELF and serum for mice administered 8/AVL. Statistical analysis was performed using Student's $t$ test.

expression in the lung as well as expression from hepatocytes, which normally produce the majority of functional AAT $(1,2,4,6,14-16,46)$. The IPL route was shown to be safe in AAV gene therapy nonhuman primate studies $(58,94)$. Additionally, IPL administration delivers $8 /$ AVL locally to a site where inflammation is unlikely to impede lung function, bypassing the respiratory epithelial route with its myriad of barriers to viral entry (95-97). IPL administration of the second-generation oxidant-resistant AAT-AVL protein expressed by the 8/AVL vector may be the ideal approach to treat AAT deficiency. 
A Male IV administration, ELF $24 \mathrm{wk}$
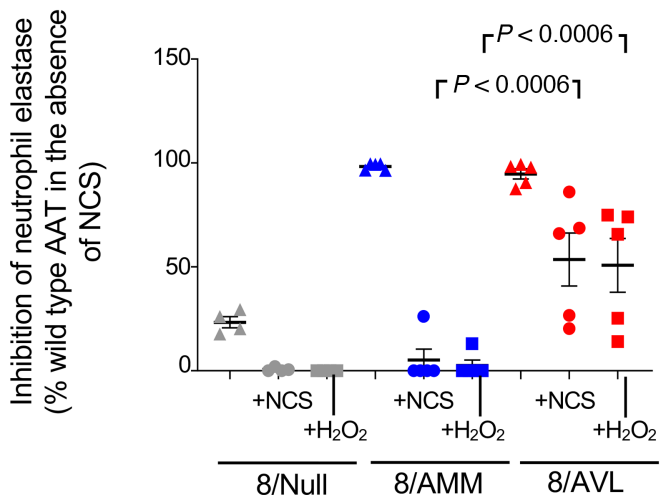

B Male IPL administration, ELF 24 wk

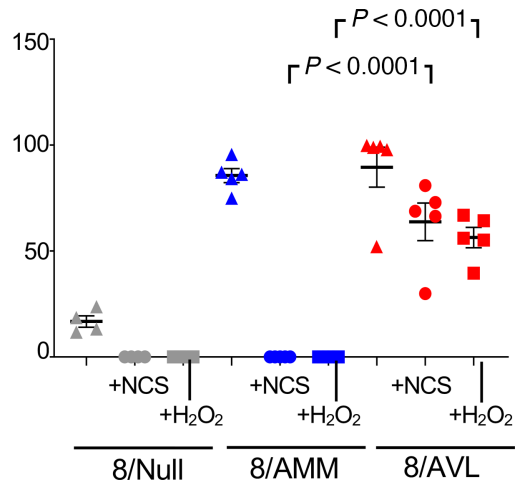

Figure 8. Anti-NE activity of human AAT in ELF from male mice administered AAV8 vectors under normal and oxidizing conditions. C57BL/ 6 male mice were administered 8/AMM, 8/AVL, or 8/Null $\left(4 \times 10^{11} \mathrm{gc}\right)$ by IV and IPL routes. ELF was collected at 24 weeks and human AAT quantified by ELISA. Equal amounts ( $50 \mathrm{nM}$ ) of AAT were used in the NE inhibition assay. Data are presented as the percentage of WT (8/AMM) NE inhibition in the absence of oxidizer. Assays were run in triplicate and averaged for samples from $n=4-5$ mice/group. Statistical analysis was performed by ANOVA. (A) IV, 24 weeks. (B) IPL, 24 weeks.

\section{Methods}

Initial testing of oxidant-resistant AAT constructs. To identify the optimal configuration of substitutions in the human AAT coding sequence at M351 and M358, site-directed mutagenesis was used to modify the 351 and 358 residues to $\mathrm{V}$ or $\mathrm{L}$ in the common, normal M1(A213) allele. We chose the M1(A213) allele as the base allele because the $\mathrm{Z}$ mutation is derived from M1(A213), so the use of the same base may minimize the potential for immune system identification of a different residue in the 213 position (e.g., V213, another common normal M1 variant; Figure 1A). To make the various combinations of 351 and 358 modifications, QuikChange II Site-Directed Mutagenesis Kit (Agilent Technologies) was used with a modified protocol. The list of the variants at 351 and 358 is in Figure 1B. Briefly, 50 ng of template DNA was mixed with $125 \mathrm{ng}$ of both forward and reverse primers for desired modification, DMSO, and 2x PfuUltra Hotstart PCR Master Mix (Agilent Technologies). Each reaction was then diluted to a final volume of $50 \mu \mathrm{L}$ with molecular grade water (Corning Life Sciences). All primers used to modify nucleotides in the template human M1(V213) AAT cDNA were from MilliporeSigma (sequences listed in Supplemental Table 1). PCR reactions were mixed on ice and amplified for 18 cycles $\left(95^{\circ} \mathrm{C}\right.$ for 50 seconds, $60^{\circ} \mathrm{C}$ for 50 seconds, and $68^{\circ} \mathrm{C}$ for 16 minutes). The PCR reaction was digested by DpnI (New England BioLabs) for 1 hour at $37^{\circ} \mathrm{C}$ to degrade template DNA. Amplified DNA was precipitated using ethanol before transforming MAX Efficiency DH5 $\alpha$ competent cells obtained from Invitrogen, Thermo Fisher Scientific, according to the manufacturer's instructions. Transformed cells were spread on LB agar plates supplemented with $50 \mu \mathrm{g} / \mathrm{mL}$ kanamycin (Teknova) and incubated overnight at $37^{\circ} \mathrm{C}$. Colonies were inoculated into LB broth supplemented with $50 \mu \mathrm{g} / \mathrm{mL}$ kanamycin shaking cultures overnight at $37^{\circ} \mathrm{C}$. Plasmid DNA was purified according to the manufacturer's instructions using the QIAprep Spin Miniprep Kit (QIAGEN). All constructs were sequenced (Genewiz) to confirm the mutations in respective plasmids. Finally, all correctly modified variants were subcloned into the AAV expression cassette containing the CMV enhancer, chicken $\beta$-actin promoter, splice donor and intron, and rabbit $\beta$-globin splice acceptor (CAG), with the modified human AAT cDNA and rabbit $\beta$-globin poly(A) site flanked by the inverted terminal repeats from AAV2 (Supplemental Figure 1).

Assessment of plasmid constructs. Human embryonic kidney 293T cells (American Type Culture Collection) were maintained in Dulbecco's modified Eagle medium (Corning Cellgro) supplemented with $10 \%$ fetal bovine serum (Life Technologies, Thermo Fisher Scientific), $1 \mathrm{mM}$ glutamine, $1 \mathrm{mM}$ sodium pyruvate, and $50 \mu \mathrm{g} / \mathrm{mL}$ gentamicin. To assess expression of the modified AAT proteins in vitro, 293T cells were transfected with $3 \mu \mathrm{g}$ modified AAT plasmid per well and harvested at 72 hours postinfection. Media from untransfected cells served as negative "mock" controls. The media were evaluated for the expression of the human AAT after concentration of sample volume using Amicon Ultra centrifugal filters (MilliporeSigma) with $10 \mathrm{kDa}$ cutoff. 
The levels of human AAT in transfection media were determined using an ELISA kit specific for human AAT (American Laboratory Products Company; ALPCO catalog 30-6752) and a highly purified AAT standard (courtesy of M. Brantly, University of Florida, Gainesville, Florida, USA).

Serine protease inhibition assays. To compare the biological activity of the AAT constructs, inhibition of $\mathrm{NE}$ activity was assessed using N-Suc-Ala-Ala-Ala- $p$-nitroanilide substrate following the manufacturer's protocol (Elastin Products Co.). All assays were performed in $100 \mu \mathrm{L}$ of Tris- $\mathrm{NaCl}$ buffer $(0.1 \mathrm{M}$ Tris pH 7.5, 0.5 M NaCl) in a 96-well plate. Human NE $(0.1 \mu \mathrm{g}$, Elastin Products) was resuspended in 0.05 $\mathrm{M}$ sodium acetate $(\mathrm{NaOAc}), \mathrm{pH} 5$, with $0.1 \mathrm{M} \mathrm{NaCl}$ and kept on ice until use. For all oxidation studies, $50 \mathrm{nM}$ AAT was preincubated with $1 \mathrm{mM}$ NCS (MilliporeSigma) for 20 minutes, $250 \mathrm{mM} \mathrm{H}_{2} \mathrm{O}_{2}$ (MilliporeSigma) for 40 minutes, or $200 \mu \mathrm{M} \mathrm{HOCl}$ (MilliporeSigma) for 30 minutes before addition of $200 \mathrm{nM}$ NE final concentration for 5 minutes. Substrate ( $2 \mathrm{mM} \mathrm{N}$-Suc-Ala-Ala-Ala- -nitroanilide) was then added, and initial reaction rates were measured by monitoring change in absorbance at $410 \mathrm{~nm}$ for 1 hour using the SpectraMax i3 plate reader (Molecular Devices, Thermo Fisher Scientific). Oxidants were not removed before addition of substrate $(36,38,76,78)$.

The assay for cathepsin G activity was carried out using N-Suc-Ala-Ala-Pro-Phe-p-nitroanilide substrate following the manufacturer's protocol (Elastin Products). All assays were carried out in $100 \mu \mathrm{L}$ of Tris-NaCl buffer (0.1 M Tris pH 7.5, 0.5 M NaCl) in a 96-well plate. Cathepsin G (0.1 $\mu \mathrm{g}$, Elastin Products) was resuspended in $0.05 \mathrm{M} \mathrm{NaOAc}, \mathrm{pH} 5$, with $0.1 \mathrm{M} \mathrm{NaCl}$ and kept on ice until use. For all oxidation studies, $200 \mathrm{nM}$ AAT was preincubated with $1 \mathrm{mM}$ NCS (MilliporeSigma) for 20 minutes or $250 \mathrm{mM} \mathrm{H}_{2} \mathrm{O}_{2}$ (MilliporeSigma) for 40 minutes before addition of $200 \mathrm{nM}$ cathepsin $\mathrm{G}$ final concentration for 5 minutes. Substrate (2 $\mathrm{mM}$ N-Suc-Ala-Ala-Pro-Phe-p-nitroanilide) was then added, and initial reaction rates were measured by monitoring change in absorbance at $410 \mathrm{~nm}$ for 1 hour using the SpectraMax i3 plate reader (Molecular Devices, Thermo Fisher Scientific). Oxidants were not removed before addition of substrate (40).

Association rate studies. Association rate studies of the AAT variants' interaction with NE were carried out with purified AAT-AMM and AAT-AVL. 293T cells were transfected with AAT plasmids, and media were harvested 72 hours posttransfection as described above. The AAT was purified using Alpha-1 Antitrypsin Select resin (17547201, GE Healthcare) according to the manufacturer's instructions. Following elution, purified AAT proteins were dialyzed into $\mathrm{PBS} \mathrm{pH}$ 7.4, concentrated using Amicon Ultra spin concentrators with $10 \mathrm{kDa}$ cutoff (MilliporeSigma), and quantified by ELISA (ALPCO). The association rate studies were performed by surface plasmon resonance on the Bio-Rad ProteOn XPR36 Protein Interaction Array System (Bio-Rad Laboratories) at the High Throughput Screening Resource Center at the Rockefeller University using a GLC sensor chip consisting of a $6 \times 6$ sample channel matrix. After initialization and conditioning according to the manufacturer's instructions, channel 1 of the GLC chip was cleaned sequentially with $0.5 \%$ sodium dodecyl sulfate, $50 \mathrm{mM} \mathrm{NaOH}$, and $100 \mathrm{mM} \mathrm{HCl}$. The channel was then activated for amine coupling with $20 \mathrm{mM}$ 1-ethyl-3-(3-dimethylaminopropyl) carbodiimide hydrochloride and 5 mM N-hydroxysulfosuccinimide (ProteOn Amine Coupling Kit, Bio-Rad Laboratories). NE was diluted to $10 \mu \mathrm{g} / \mathrm{mL}$ in $50 \mathrm{mM}$ acetate buffer, $\mathrm{pH}$ 5.5, and flowed across the sensor chip to allow binding, and the response units were recorded. The chip was quenched with $1 \mathrm{M}$ ethanolamine $\mathrm{pH}$ 8.5. The running buffer during NE-binding steps was $10 \mathrm{mM}$ HEPES, $150 \mathrm{mM} \mathrm{NaCl}$, and $0.01 \%$ Tween-20. After completion of $\mathrm{NE}$ binding, the running buffer was switched to $10 \mathrm{mM}$ HEPES, $150 \mathrm{mM} \mathrm{NaCl}, 0.01 \%$ Tween-20, and 2 $\mathrm{mg} / \mathrm{mL}$ bovine serum albumin (BSA binding buffer). Purified AAT was diluted to $1000 \mathrm{nM}$ in BSA binding buffer, and 2-fold serial dilutions were made in BSA binding buffer to $62.5 \mathrm{nM}$. Buffer alone was used as a blank. Each AAT dilution, in separate lanes (1-6), was flowed simultaneously across the NE-bound channel for 60 seconds to allow association to occur, with the wash delay set for 600 seconds to allow for dissociation. The $K_{a}$ was calculated by ProteOn Manager software (Bio-Rad Laboratories) using the kinetic Langmuir binding model with simultaneous calculation of binding association and dissociation rates (98). The process was repeated as described for each AAT variant and condition starting with binding NE to a new channel for each experiment because the interaction between NE and AAT is irreversible. For binding under oxidizing conditions, AAT purified protein was incubated with $1 \mathrm{mM}$ NCS for 20 minutes before dilution in BSA binding buffer. The running buffer for experiments under oxidizing conditions was $10 \mathrm{mM}$ HEPES, $150 \mathrm{mM} \mathrm{NaCl}, 0.01 \%$ Tween-20, $2 \mathrm{mg} / \mathrm{mL}$ BSA, and $4.75 \mu \mathrm{M}$ NCS. In all cases, the $\chi^{2}$ value for goodness of fit was less than $10 \%$ of $\mathrm{R}_{\max }$, indicating that the data were a good fit for the binding model.

AAV8-based gene transfer vectors. The AAV8 vectors were produced using 293T cells with a 3-plasmid transfection system as described previously (61). Briefly, the pAAV-CAG-hAAT expression plasmid (55 $\mu$ g), AAV8 
packaging plasmid containing Rep (derived from AAV2) and Cap (derived from AAV8) proteins (550 $\mu$ g), and pAdDeltaF6 adenovirus helper plasmid $(1100 \mu \mathrm{g})$ were cotransfected into 293T cells using PEI transfection reagent (Polysciences). At 72 hours posttransfection, cells were harvested and lysate prepared using 5 cycles of freeze/thaw. Cell lysate containing the virus was clarified by centrifugation at $2675 \mathrm{~g}$ for 15 minutes. The AAV8 vectors were purified from the crude viral lysate by iodixanol gradient. Vectors were diluted in PBS, $\mathrm{pH} 7.4$, with $5 \%$ glycerol and $35 \mathrm{mM} \mathrm{NaCl}$. Iodixanol was removed by dialysis using Slide-A-Lyzer Dialysis cassettes (12-30 mL, $20 \mathrm{kDa}$ cutoff; Thermo Fisher Scientific). Vectors were concentrated using a Vivaspin 20 $100 \mathrm{~K}$ membrane concentrator (GE Healthcare) and stored in PBS, $5 \%$ glycerol, and $35 \mathrm{mM} \mathrm{NaCl}$ at $-80^{\circ} \mathrm{C}$.

IV and IPL vector delivery. 8/AMM, 8/AVL, and 8/null vectors $\left(4 \times 10^{10}, 10^{11}, 4 \times 10^{11} \mathrm{gc}\right)$ were delivered either IV or IPL to the left lung of 6 - to 8 -week-old C57BL/6 mice ( $n=4$ to 5) (61). For the IPL administration, the mice were anesthetized in the right lateral position with a combination of isoflurane (1\% to $3 \%$ inhalation), buprenorphine ( $0.1 \mathrm{mg} / \mathrm{kg}$ subcutaneously), and bupivacaine ( $2 \mathrm{mg} / \mathrm{kg}$, subcutaneously). An anterolateral chest skin incision approximately $1 \mathrm{~cm}$ in length was made using scissors and the thoracic cage was exposed. The third rib was lifted with tweezers, and the IPL injection via the third intercostal space was performed using a $1 \mathrm{~mL}$ insulin syringe. All doses of AAV vectors were administered in $100 \mu \mathrm{L}$ of PBS. The skin was closed with 4-0 absorbable suture (Polysorb). Sutures were removed within 2 weeks. For IV delivery, AAV vectors were administered in $100 \mu \mathrm{L}$ of PBS via the tail vein using a $1 \mathrm{~mL}$ insulin syringe.

Sample collection. Serum was collected at $0,4,8,12,20$, and 24 weeks by drawing $200 \mu \mathrm{L}$ of blood from the tail vein in $\mathrm{BD}$ Microtainer SST tubes (Becton Dickinson). The blood samples were allowed to clot for 10 minutes at $23^{\circ} \mathrm{C}$ and then spun in a microcentrifuge at $2000 \mathrm{~g}$ for 10 minutes at $4^{\circ} \mathrm{C}$ to collect serum. Mice were euthanized at weeks 4,12 , or 24 after vector administration using $\mathrm{CO}_{2}$ inhalation followed by cardiac perfusion with $40 \mathrm{~mL}$ cold PBS, $\mathrm{pH}$ 7.4. Livers were collected and immediately frozen on dry ice.

Immediately after being euthanized by $\mathrm{CO}_{2}$, mice were fixed in the supine position. The diaphragm was cut open and trachea exposed. The anterior wall of the trachea was cut, a 23-G angiocatheter was inserted, and the orifice was tied with 4-0 silk, including the inserted angiocatheter to keep the airway closed. Five hundred microliters PBS was injected and flushed twice and then collected. Lavage samples were kept on ice until processing by centrifugation at $10,000 \mathrm{~g}$ for 5 minutes at $4^{\circ} \mathrm{C}$ to remove any cells, and then supernatant was stored at $-80^{\circ} \mathrm{C}(99)$.

Analysis of serum and ELF. Serum and ELF collected from mice at various time points were analyzed for human AAT levels by ELISA (ALPCO). Total protein in ELF was determined using the Pierce BCA Protein Assay Kit (Thermo Fisher Scientific). Inhibitory capacity of AAT in serum and ELF was assessed under normal and oxidizing conditions using the NE and cathepsin $\mathrm{G}$ inhibition assays as described above.

Vector genome DNA analysis. Vector genome DNA levels were assessed in the liver to evaluate persistence. Livers were weighed and homogenized in $1.5 \mathrm{~mL}$ of lysis buffer containing $10 \mathrm{mM} \mathrm{HEPES} \mathrm{KOH,}$ pH 7.4; 5 mM mannitol; and 1\% Triton X-100 per liver using $2.5 \mathrm{~mm}$ stainless steel beads in a TissueLyzer LT (QIAGEN) until no visible chunks remained (5 minutes at a time) at an oscillation of 50/s (100). The homogenate was collected, pooled, and stored at $-80^{\circ} \mathrm{C}$. Genomic DNA was isolated from the liver homogenate using the DNeasy Blood and Tissue kit (QIAGEN) from $200 \mu \mathrm{L}$ of homogenate according to the manufacturer's instructions. The total amount of DNA extracted was measured using a UV spectrophotometer (NanoDrop ND-1000, Thermo Fisher Scientific). The human AAT cDNA transgene contains silent changes in the last 200 nucleotides for detection by quantitative polymerase chain reaction (qPCR) (58). Human AAT gene expression was quantified by TaqMan qPCR with a FAM-labeled transgene specific primer/probe set (4331348, Applied Biosystems, Thermo Fisher Scientific) (58). Using relative quantification, $500 \mathrm{ng}$ /well from the total DNA extracted was assayed and compared with a standard curve created by pAAV-CAG-hAAT plasmid that spanned the range of $10^{2}-10^{9} \mathrm{gc}$ per well (slope $-3.48 ; r^{2}=0.999$ ). The efficiency of DNA extraction was measured by using a VIC-labeled housekeeping murine Tfrc gene specific primer/probe set (4458366, Applied Biosystems, Thermo Fisher Scientific) and compared with a predetermined specification (Ct value of $28.3 \pm 4.3$ ).

Statistics. All data are expressed as either geometric means (for serum titers) or group means (AAT levels) \pm SEM. Comparisons for experimental groups were performed with 2-tailed Student's $t$ test and 1-way ANOVA for multiple comparisons within data sets.

Study approval. All mouse experiments conformed to the relevant regulatory standards and were approved by the Institutional Animal Care and Use Committee at Weill Cornell Medical College (WCMC 2014-0054). 


\section{Author contributions}

MLS and KMS designed and performed experiments, analyzed data, and wrote the manuscript; EZF, FMH, and YM performed experiments; BPD and SMK analyzed data; and RGC designed experiments, analyzed data, and wrote the manuscript.

\section{Acknowledgments}

We thank J. Reid and E. Papadopoulos for technical assistance, M. Brantly (University of Florida) for advice, C. Adura Alcaino (High Throughput Resource Screening Center, the Rockefeller University) for guidance with surface plasmon resonance technique, and N. Mohamed for editorial support. These studies were supported, in part, by LEXEO Therapeutics via NIH R42 HL140670 and in part by the Department of Genetic Medicine. MLS was supported by NIH T32 HL094284. Research reported in this publication was supported by the National Heart, Lung, and Blood Institute/NIH. The content is solely the responsibility of the authors and does not necessarily represent the official views of the NIH.

Address correspondence to: Ronald G. Crystal, Department of Genetic Medicine, Weill Cornell Medical College, 1300 York Avenue, Box 164, New York, New York 10065, USA. Phone: 646.962.4363; Email: geneticmedicine@med.cornell.edu.

1. Brantly M, Nukiwa T, Crystal RG. Molecular basis of alpha-1-antitrypsin deficiency. Am J Med. 1988;84(6A):13-31.

2. Crystal RG. Alpha 1-antitrypsin deficiency, emphysema, and liver disease. Genetic basis and strategies for therapy. J Clin Invest. 1990;85(5):1343-1352.

3. The Alpha-1-Antitrypsin Deficiency Registry Study Group. Survival and FEV1 decline in individuals with severe deficiency of alpha1-antitrypsin. Am J Respir Crit Care Med. 1998;158(1):49-59.

4. Silverman EK, Sandhaus RA. Clinical practice. Alpha1-antitrypsin deficiency. NEngl J Med. 2009;360(26):2749-2757.

5. de Serres FJ, Blanco I. Prevalence of $\alpha 1$-antitrypsin deficiency alleles $\mathrm{PI}^{*} \mathrm{~S}$ and $\mathrm{PI}{ }^{\star} \mathrm{Z}$ worldwide and effective screening for each of the five phenotypic classes $\mathrm{PI}^{*} \mathrm{MS}, \mathrm{PI}^{*} \mathrm{MZ}, \mathrm{PI}^{*} \mathrm{SS}, \mathrm{PI}^{*} \mathrm{SZ}$, and $\mathrm{PI}{ }^{*} \mathrm{ZZ}$ : a comprehensive review. Ther Adv Respir Dis. 2012;6(5):277-295.

6. Brantly ML, Paul LD, Miller BH, Falk RT, Wu M, Crystal RG. Clinical features and history of the destructive lung disease associated with alpha-1-antitrypsin deficiency of adults with pulmonary symptoms. Am Rev Respir Dis. 1988;138(2):327-336

7. Lomas DA, Parfrey H. Alpha1-antitrypsin deficiency. 4: molecular pathophysiology. Thorax. 2004;59(6):529-535.

8. Tanash HA, Nilsson PM, Nilsson JA, Piitulainen E. Survival in severe alpha-1-antitrypsin deficiency (PiZZ). Respir Res. 2010;11:44

9. Gadek JE, Fells GA, Zimmerman RL, Rennard SI, Crystal RG. Antielastases of the human alveolar structures. Implications for the protease-antiprotease theory of emphysema. J Clin Invest. 1981;68(4):889-898.

10. Carrell RW. alpha 1-Antitrypsin: molecular pathology, leukocytes, and tissue damage. J Clin Invest. 1986;78(6):1427-1431.

11. Duranton J, Bieth JG. Inhibition of proteinase 3 by [alpha]1-antitrypsin in vitro predicts very fast inhibition in vivo. Am J Respir Cell Mol Biol. 2003;29(1):57-61.

12. Petrache I, et al. alpha-1 antitrypsin inhibits caspase-3 activity, preventing lung endothelial cell apoptosis. Am J Pathol. 2006;169(4):1155-1166.

13. Lungarella G, Cavarra E, Lucattelli M, Martorana PA. The dual role of neutrophil elastase in lung destruction and repair. Int $J$ Biochem Cell Biol. 2008;40(6-7):1287-1296.

14. Tuder RM, Janciauskiene SM, Petrache I. Lung disease associated with alpha1-antitrypsin deficiency. Proc Am Thorac Soc. 2010;7(6):381-386.

15. Greene CM, et al. Alpha-1 antitrypsin deficiency: a conformational disease associated with lung and liver manifestations. J Inherit Metab Dis. 2008;31(1):21-34.

16. Alam S, Li Z, Atkinson C, Jonigk D, Janciauskiene S, Mahadeva R. Z $\alpha 1$-antitrypsin confers a proinflammatory phenotype that contributes to chronic obstructive pulmonary disease. Am J Respir Crit Care Med. 2014;189(8):909-931.

17. van 't Wout EF, van Schadewijk A, Savage ND, Stolk J, Hiemstra PS. $\alpha 1$-antitrypsin production by proinflammatory and antiinflammatory macrophages and dendritic cells. Am J Respir Cell Mol Biol. 2012;46(5):607-613.

18. Reyfman PA, et al. Single-cell transcriptomic analysis of human lung provides insights into the pathobiology of pulmonary fibrosis. Am J Respir Crit Care Med. 2019;199(12):1517-1536.

19. Schiller HB, et al. The Human Lung Cell Atlas: a high-resolution reference map of the human lung in health and disease. Am $J$ Respir Cell Mol Biol. 2019;61(1):31-41.

20. Putnam CW, Porter KA, Peters RL, Ashcavai M, Redeker AG, Starzl TE. Liver replacement for alpha1-antitrypsin deficiency. Surgery. 1977;81(3):258-261.

21. Combs C, Brunt EM, Solomon H, Bacon BR, Brantly M, Di Bisceglie AM. Rapid development of hepatic alpha1-antitrypsin globules after liver transplantation for chronic hepatitis C. Gastroenterology. 1997;112(4):1372-1375.

22. Fagiuoli S, Daina E, D'Antiga L, Colledan M, Remuzzi G. Monogenic diseases that can be cured by liver transplantation. $J$ Hepatol. 2013;59(3):595-612.

23. Crystal RG, Brantly ML, Hubbard RC, Curiel DT, States DJ, Holmes MD. The alpha 1-antitrypsin gene and its mutations. Clinical consequences and strategies for therapy. Chest. 1989;95(1):196-208.

24. Carrell R, Travis J. a1-Antitrypsin and the serpins: variation and countervariation. Trends Biochem Sci. 1985;10(1):20-24. 
25. Chiuchiolo MJ, Crystal RG. Gene therapy for alpha-1 antitrypsin deficiency lung disease. Ann Am Thorac Soc. 2016;13(supp1 4):S352-S369.

26. Jeppsson JO. Amino acid substitution Glu leads to Lys alpha1-antitrypsin PiZ. FEBS Lett. 1976;65(2):195-197.

27. Bornhorst JA, Greene DN, Ashwood ER, Grenache DG. $\alpha 1$-Antitrypsin phenotypes and associated serum protein concentrations in a large clinical population. Chest. 2013;143(4):1000-1008.

28. de Serres F, Blanco I. Role of alpha-1 antitrypsin in human health and disease. J Intern Med. 2014;276(4):311-335.

29. Brantly M, Courtney M, Crystal RG. Repair of the secretion defect in the Z form of alpha 1-antitrypsin by addition of a second mutation. Science. 1988;242(4886):1700-1702.

30. Lomas DA, Evans DL, Finch JT, Carrell RW. The mechanism of Z alpha 1-antitrypsin accumulation in the liver. Nature. 1992;357(6379):605-607.

31. Gooptu B, Lomas DA. Conformational pathology of the serpins: themes, variations, and therapeutic strategies. Annu Rev Biochem. 2009;78:147-176.

32. Loebermann H, Tokuoka R, Deisenhofer J, Huber R. Human alpha 1-proteinase inhibitor. Crystal structure analysis of two crystal modifications, molecular model and preliminary analysis of the implications for function. J Mol Biol. 1984;177(3):531-557.

33. Elliott PR, Lomas DA, Carrell RW, Abrahams JP. Inhibitory conformation of the reactive loop of alpha 1-antitrypsin. Nat Struct Biol. 1996;3(8):676-681.

34. Gadek JE, Fells GA, Crystal RG. Cigarette smoking induces functional antiprotease deficiency in the lower respiratory tract of humans. Science. 1979;206(4424):1315-1316.

35. Buhl R, Meyer A, Vogelmeier C. Oxidant-protease interaction in the lung. Prospects for antioxidant therapy. Chest. 1996;110(suppl 6):267S-272S.

36. Johnson D, Travis J. The oxidative inactivation of human alpha-1-proteinase inhibitor. Further evidence for methionine at the reactive center. J Biol Chem. 1979;254(10):4022-4026.

37. Matheson NR, Wong PS, Travis J. Enzymatic inactivation of human alpha-1-proteinase inhibitor by neutrophil myeloperoxidase. Biochem Biophys Res Commun. 1979;88(2):402-409.

38. Beatty K, Bieth J, Travis J. Kinetics of association of serine proteinases with native and oxidized alpha-1-proteinase inhibitor and alpha-1-antichymotrypsin. J Biol Chem. 1980;255(9):3931-3934.

39. Carp H, Janoff A. Potential mediator of inflammation. Phagocyte-derived oxidants suppress the elastase-inhibitory capacity of alpha 1-proteinase inhibitor in vitro. J Clin Invest. 1980;66(5):987-995.

40. Taggart C, et al. Oxidation of either methionine 351 or methionine 358 in alpha 1-antitrypsin causes loss of anti-neutrophil elastase activity. J Biol Chem. 2000;275(35):27258-27265.

41. Summers FA, Morgan PE, Davies MJ, Hawkins CL. Identification of plasma proteins that are susceptible to thiol oxidation by hypochlorous acid and N-chloramines. Chem Res Toxicol. 2008;21(9):1832-1840.

42. Topic A, Radojkovic D. Polymerization and oxidation of alpha-1-antitrypsin in pathogenesis of emphysema, lung diseases. In: Irusen E, ed. Lung Diseases: Selected State of the Art Reviews. InTech; 2012:55-82. Accessed July 15, 2020. https://www. intechopen.com/books/lung-diseases-selected-state-of-the-art-reviews/polymerization-and-oxidation-of-alpha-1-antitrypsin-in-pathogenesis-of-emphysema.

43. Cohen AB, James HL. Reduction of the elastase inhibitory capacity of alpha 1-antitrypsin by peroxides in cigarette smoke: an analysis of brands and filters. Am Rev Respir Dis. 1982;126(1):25-30.

44. Evans MD, Pryor WA. Cigarette smoking, emphysema, and damage to alpha 1-proteinase inhibitor. Am J Physiol. 1994;266(6 pt 1):L593-L611.

45. Alam S, Li Z, Janciauskiene S, Mahadeva R. Oxidation of $\mathrm{Z} \alpha 1$-antitrypsin by cigarette smoke induces polymerization: a novel mechanism of early-onset emphysema. Am J Respir Cell Mol Biol. 2011;45(2):261-269.

46. Gadek JE, Klein HG, Holland PV, Crystal RG. Replacement therapy of alpha 1-antitrypsin deficiency. Reversal of protease-antiprotease imbalance within the alveolar structures of PiZ subjects. J Clin Invest. 1981;68(5):1158-1165.

47. Wewers MD, et al. Replacement therapy for alpha 1-antitrypsin deficiency associated with emphysema. $N$ Engl J Med. 1987;316(17):1055-1062.

48. American Thoracic Society, European Respiratory Society. American Thoracic Society/European Respiratory Society statement: standards for the diagnosis and management of individuals with alpha-1 antitrypsin deficiency. Am J Respir Crit Care Med. 2003;168(7):818-900.

49. Crystal RG. Augmentation treatment for $\alpha 1$ antitrypsin deficiency. Lancet. 2015;386(9991):318-320.

50. Chapman KR, et al. Intravenous augmentation treatment and lung density in severe $\alpha 1$ antitrypsin deficiency (RAPID): a randomised, double-blind, placebo-controlled trial. Lancet. 2015;386(9991):360-368.

51. Crystal RG. Compelling evidence for the efficacy of $\alpha 1$-antitrypsin augmentation treatment for $\alpha 1$-antitrypsin deficiency. Lancet Respir Med. 2017;5(1):7-8.

52. McElvaney NG, et al. Long-term efficacy and safety of $\alpha 1$ proteinase inhibitor treatment for emphysema caused by severe $\alpha 1$ antitrypsin deficiency: an open-label extension trial (RAPID-OLE). Lancet Respir Med. 2017;5(1):51-60.

53. Thompson Healthcare 2010. Red Book: Pharmacy's Fundamental Reference. Thomson Reuters: PDR Network;2010.

54. Stoller JK, Aboussouan LS. A review of a1-antitrypsin deficiency. Am J Respir Crit Care Med. 2012;185(3):246-259

55. De B, et al. Intrapleural administration of a serotype 5 adeno-associated virus coding for alpha1-antitrypsin mediates persistent, high lung and serum levels of alpha1-antitrypsin. Mol Ther. 2004;10(6):1003-1010.

56. Conlon TJ, et al. Efficient hepatic delivery and expression from a recombinant adeno-associated virus 8 pseudotyped alpha1-antitrypsin vector. Mol Ther. 2005;12(5):867-875.

57. Chulay JD, et al. Preclinical evaluation of a recombinant adeno-associated virus vector expressing human alpha-1 antitrypsin made using a recombinant herpes simplex virus production method. Hum Gene Ther. 2011;22(2):155-165.

58. Chiuchiolo MJ, et al. Intrapleural administration of an AAVrh.10 vector coding for human $\alpha 1$-antitrypsin for the treatment of $\alpha 1$-antitrypsin deficiency. Hum Gene Ther Clin Dev. 2013;24(4):161-173.

59. Brantly ML, et al. Phase I trial of intramuscular injection of a recombinant adeno-associated virus serotype 2 alphal-antitrypsin (AAT) vector in AAT-deficient adults. Hum Gene Ther. 2006;17(12):1177-1186. 
60. Brantly ML, et al. Sustained transgene expression despite T lymphocyte responses in a clinical trial of rAAV1-AAT gene therapy. Proc Natl Acad Sci USA. 2009;106(38):16363-16368.

61. De BP, et al. High levels of persistent expression of alpha1-antitrypsin mediated by the nonhuman primate serotype rh.10 adeno-associated virus despite preexisting immunity to common human adeno-associated viruses. Mol Ther. 2006;13(1):67-76.

62. Flotte TR, Conlon TJ, Poirier A, Campbell-Thompson M, Byrne BJ. Preclinical characterization of a recombinant adeno-associated virus type 1-pseudotyped vector demonstrates dose-dependent injection site inflammation and dissemination of vector genomes to distant sites. Hum Gene Ther. 2007;18(3):245-256.

63. Flotte TR, et al. Phase 2 clinical trial of a recombinant adeno-associated viral vector expressing $\alpha 1$-antitrypsin: interim results. Hum Gene Ther. 2011;22(10):1239-1247.

64. Halbert CL, et al. Expression of human alpha1-antitrypsin in mice and dogs following AAV6 vector-mediated gene transfer to the lungs. Mol Ther. 2010;18(6):1165-1172.

65. Limberis MP, Wilson JM. Adeno-associated virus serotype 9 vectors transduce murine alveolar and nasal epithelia and can be readministered. Proc Natl Acad Sci U S A. 2006;103(35):12993-12998.

66. Limberis MP, Vandenberghe LH, Zhang L, Pickles RJ, Wilson JM. Transduction efficiencies of novel AAV vectors in mouse airway epithelium in vivo and human ciliated airway epithelium in vitro. Mol Ther. 2009;17(2):294-301.

67. Lu Y, et al. Therapeutic level of functional human alpha 1 antitrypsin (hAAT) secreted from murine muscle transduced by adeno-associated virus (rAAV1) vector. J Gene Med. 2006;8(6):730-735.

68. Mueller C, et al. 5 year expression and neutrophil defect repair after gene therapy in alpha-1 antitrypsin deficiency. Mol Ther. 2017;25(6):1387-1394.

69. Song S, et al. Sustained secretion of human alpha-1-antitrypsin from murine muscle transduced with adeno-associated virus vectors. Proc Natl Acad Sci USA. 1998;95(24):14384-14388.

70. Song S, Embury J, Laipis PJ, Berns KI, Crawford JM, Flotte TR. Stable therapeutic serum levels of human alpha-1 antitrypsin (AAT) after portal vein injection of recombinant adeno-associated virus (rAAV) vectors. Gene Ther. 2001;8(17):1299-1306.

71. Song S et al. Recombinant adeno-associated virus-mediated alpha-1 antitrypsin gene therapy prevents type I diabetes in NOD mice. Gene Ther. 2004;11(2):181-186.

72. Virella-Lowell I, et al. Enhancing rAAV vector expression in the lung. J Gene Med. 2005;7(7):842-850.

73. Xiao W, Berta SC, Lu MM, Moscioni AD, Tazelaar J, Wilson JM. Adeno-associated virus as a vector for liver-directed gene therapy. J Virol. 1998;72(12):10222-10226.

74. Rosenberg S, Barr PJ, Najarian RC, Hallewell RA. Synthesis in yeast of a functional oxidation-resistant mutant of human alpha-antitrypsin. Nature. 1984;312(5989):77-80.

75. Courtney M, Jallat S, Tessier LH, Benavente A, Crystal RG, Lecocq JP. Synthesis in E. coli of alpha 1-antitrypsin variants of therapeutic potential for emphysema and thrombosis. Nature. 1985;313(5998):149-151.

76. Jallat S, Tessier LH, Benavente A, Crystal RG, Courtney M. Antiprotease targeting: altered specificity of alpha 1-antitrypsin by amino acid replacement at the reactive centre. Rev Fr Transfus Immunohematol. 1986;29(4):287-298.

77. Zhu W, et al. Oxidation-resistant and thermostable forms of alpha-1 antitrypsin from Escherichia coli inclusion bodies. FEBS Open Bio. 2018;8(10):1711-1721.

78. Janoff A, George-Nascimento C, Rosenberg S. A genetically engineered, mutant human alpha-1-proteinase inhibitor is more resistant than the normal inhibitor to oxidative inactivation by chemicals, enzymes, cells, and cigarette smoke. Am Rev Respir Dis. 1986;133(3):353-356.

79. Luisetti M, Seersholm N. Alpha1-antitrypsin deficiency. 1: epidemiology of alpha1-antitrypsin deficiency. Thorax. 2004;59(2):164-169

80. Silberstein DZ, Karuppanan K, Aung HH, Chen CH, Cross CE, McDonald KA. An oxidation-resistant, recombinant alpha-1 antitrypsin produced in Nicotiana benthamiana. Free Radic Biol Med. 2018;120:303-310.

81. Eckelman BP, Timmer JC, Deveraux Q. Serpin fusion polypeptides and methods of use thereof. Google Patents. https:// patents.google.com/patent/US8980266B2/en. Accessed July 15, 2020.

82. Luisetti $\mathrm{M}$, et al. Alpha 1-antitrypsin variants produced by recombinant DNA: differences in elastase inhibitory activity and resistance to oxidant agents. Int J Tissue React. 1990;12(6):363-368.

83. Dane AP, Wowro SJ, Cunningham SC, Alexander IE. Comparison of gene transfer to the murine liver following intraperitoneal and intraportal delivery of hepatotropic AAV pseudo-serotypes. Gene Ther. 2013;20(4):460-464.

84. Davidoff AM, Ng CY, Zhou J, Spence Y, Nathwani AC. Sex significantly influences transduction of murine liver by recombinant adeno-associated viral vectors through an androgen-dependent pathway. Blood. 2003;102(2):480-488.

85. Winterbourn CC. Comparative reactivities of various biological compounds with myeloperoxidase-hydrogen peroxide-chloride, and similarity of the oxidant to hypochlorite. Biochim Biophys Acta. 1985;840(2):204-210.

86. Bernstein JA, et al. Health effects of air pollution. J Allergy Clin Immunol. 2004;114(5):1116-1123.

87. Ciencewicki J, Trivedi S, Kleeberger SR. Oxidants and the pathogenesis of lung diseases. J Allergy Clin Immunol. 2008;122(3):456-469.

88. Hubbard RC, et al. Oxidants spontaneously released by alveolar macrophages of cigarette smokers can inactivate the active site of alpha 1-antitrypsin, rendering it ineffective as an inhibitor of neutrophil elastase. J Clin Invest. 1987;80(5):1289-1295.

89. Dasí FAM, Sanz F, Codoñer-Franch P, Navarro-García MM, Escribano A. Oxidative stress in serum of patients with alpha-1 antitrypsin deficiency. Eur Respir J. 2013;42(suppl 57):1488.

90. Zhu W, et al. Oxidation-resistant and thermostable forms of alpha-1 antitrypsin from Escherichia coli inclusion bodies. FEBS Open Bio. 2018;8(10):1711-1721.

91. Sandoval C, Curtis H, Congote LF. Enhanced proliferative effects of a baculovirus-produced fusion protein of insulin-like growth factor and alpha(1)-proteinase inhibitor and improved anti-elastase activity of the inhibitor with glutamate at position 351. Protein Eng. 2002;15(5):413-418.

92. Finley DJ, Rusch VW. Anatomy of the pleura. Thorac Surg Clin. 2011;21(2):157-163.

93. Negrini D, Moriondo A. Pleural function and lymphatics. Acta Physiol (Oxf). 2013;207(2):244-259.

94. Stiles KM, Sondhi D, Kaminsky SM, De BP, Rosenberg JB, Crystal RG. Intrapleural gene therapy for alpha-1 antitrypsin defi- 
ciency-related lung disease. Chronic Obstr Pulm Dis. 2018;5(4):244-257.

95. Pickles RJ. Physical and biological barriers to viral vector-mediated delivery of genes to the airway epithelium. Proc Am Thorac Soc. 2004;1(4):302-308.

96. Light RW. Pleural Diseases. Wolters Kluwer/Lippincott, Williams \& Wilkins;2001.

97. Heguy A, Crystal RG. Intrapleural 'outside-in' gene therapy: therapeutics for organs of the chest via gene transfer to the pleura. Curr Opin Mol Ther. 2005;7(5):440-453.

98. Luo R. Guide to SPR data analysis on the ProteOn ${ }^{\mathrm{TM}}$ XPR36 System. Bioradiations website. https://www.bioradiations.com/ guide-to-spr-data-analysis-on-the-proteon-xpr36-system/. Published July 9, 2013. Accessed July 15, 2020

99. Van Hoecke L, Job ER, Saelens X, Roose K. Bronchoalveolar lavage of murine lungs to analyze inflammatory cell infiltration. $J$ Vis Exp. 2017;(123):55398

100. De BP, et al. In vivo potency assay for adeno-associated virus-based gene therapy vectors using AAVrh. 10 as an example. Hum Gene Ther Methods. 2018;29(3):146-155.

101. Nukiwa T, et al. Identification of a second mutation in the protein-coding sequence of the $\mathrm{Z}$ type alpha 1-antitrypsin gene. $J$ Biol Chem. 1986;261(34):15989-15994.

102. Seixas S, Garcia O, Trovoada MJ, Santos MT, Amorim A, Rocha J. Patterns of haplotype diversity within the serpin gene cluster at 14q32.1: insights into the natural history of the alpha1-antitrypsin polymorphism. Hum Genet. 2001;108(1):20-30. 